\title{
Too close for comfort
}

Nancy Haigwood, director of the Oregon National Primate Research Center, describes her encounters with anthrax suspect Bruce Ivins.

RexDalton

In early 2002, the US Federal Bureau of Investigation (FBI) asked the American Society for Microbiology to canvas its 43,000 members for information about the 2001 anthrax mail attacks that killed five people. Nancy Haigwood, now director of the Oregon National Primate Research Center in Hillsboro, suggested that agents should investigate microbiologist Bruce Ivins, who had been harassing her for more than 20 years. On 29 July, Ivins killed himself as authorities were close to indicting him for the anthrax attacks.

\section{When did you first meet Ivins?}

In 1976, he was a postdoc and I was a graduate student in the department of bacteriology and immunology at University of North Carolina (UNC) in Chapel Hill. I may have gone out for a sandwich with Ivins and his wife together.

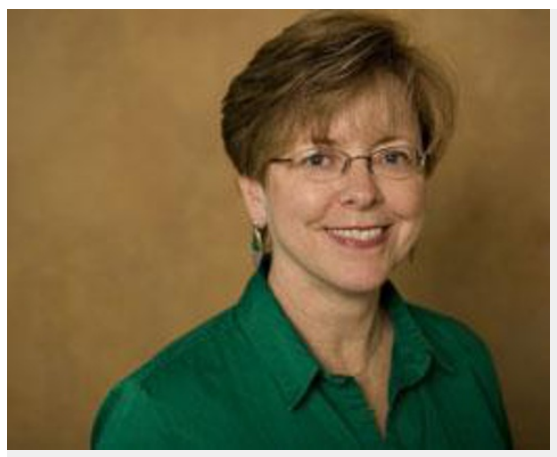

Nancy Haigwood.

\section{When did his behaviour first concern you?}

In 1982, my house and first-husband's car were vandalized, marked with KKG [Ivins had an obsessive hatred of the Kappa Kappa Gamma sorority, of which Haigwood was a member]. A letter was also ghost-written in my name to a newspaper. I knew it had to be Ivins. I confronted him on the telephone. He denied it. Later, I came to believe that he had stolen a lab book frommy UNC locker in 1979. An anonymous note said I could find my missing book in a particular US Post Office Box. What now looks significant is the use of the postal box.

Why did you link Ivins to the anthrax attacks?

I had been getting regular e-mail updates from him. In November 2001, two months after the attacks, he sent out e-mails and photos of himself working with anthrax at the Fort Detrick lab.

Did the FBI ask you to meet with Ivins and wear a hidden recording device?

Yes. I came close to setting a meeting up. I was going to have lunch with him when visiting Washington DC. Ultimately, I couldn't do it. I was afraid. The FBI told me there might be guns involved. I would be surrounded by disguised agents. But the agents thought I would be too nervous to do it.

\section{What are your thoughts about Ivins's death?}

I was shocked. There was some relief. You never want someone you know to do something like the anthrax attacks. But he must have felt cornered - and he was.

\section{Do you have any doubts that Ivins was behind the anthrax mailings?}

I have not seen all the evidence. But I have read the October 2007 affidavit to search his house. It tied the mailed anthrax spores to Ivins's flask. I don't think he intended to kill people, but to scare them. Now I know he stood to gain from business from his work.

\section{What is the most significant evidence?}

The genetic evidence. And, he intentionally gave the FBI the wrong sample. He covered up an anthrax spill at his lab. He checked out a freeze drier late at night, exactly what you would need to make the mailed spores. All this piles up. But the mailings from a box near the KKG house in Princeton, New Jersey, that was the icing on the cake — a diabolical little twist that is so Ivins.

\section{What should happen next?}

I would like to see a scientific paper published on this. I have no reason to doubt the FBI; I met a half-dozen agents, I got to know two very well. But the scientific community needs to see all the data. * 